\title{
Understanding the impact on climate change of convenience food: Carbon footprint of sandwiches
}

DOI:

10.1016/j.spc.2017.12.002

Document Version

Accepted author manuscript

Link to publication record in Manchester Research Explorer

\section{Citation for published version (APA):}

Espinoza-Orias, N., \& Azapagic, A. (2018). Understanding the impact on climate change of convenience food: Carbon footprint of sandwiches. Sustainable Production and Consumption, 15, 1-15.

https://doi.org/10.1016/j.spc.2017.12.002

\section{Published in:}

Sustainable Production and Consumption

\section{Citing this paper}

Please note that where the full-text provided on Manchester Research Explorer is the Author Accepted Manuscript or Proof version this may differ from the final Published version. If citing, it is advised that you check and use the publisher's definitive version.

\section{General rights}

Copyright and moral rights for the publications made accessible in the Research Explorer are retained by the authors and/or other copyright owners and it is a condition of accessing publications that users recognise and abide by the legal requirements associated with these rights.

\section{Takedown policy}

If you believe that this document breaches copyright please refer to the University of Manchester's Takedown Procedures [http://man.ac.uk/04Y6Bo] or contact uml.scholarlycommunications@manchester.ac.uk providing relevant details, so we can investigate your claim.

\section{OPEN ACCESS}


Accepted for publication in Sustainable Production and Consumption: https://doi.org/10.1016/i.spc.2017.12.002

\title{
Understanding the impact on climate change of convenience food: Carbon footprint of sandwiches
}

\author{
Namy Espinoza-Orias and Adisa Azapagic*
}

Sustainable Industrial Systems, School of Chemical Engineering and Analytical Sciences, The University of Manchester, Manchester M13 9PL, UK

${ }^{*}$ Corresponding author: adisa.azapagic@manchester.ac.uk

\begin{abstract}
Sandwiches are ubiquitous food items and yet little is known about their environmental impacts. This paper focused on their impact on climate change and estimated the carbon footprint of commercial and home-made sandwiches. The study also explored how the information on the carbon footprint could be combined with nutritional data to assist consumers in making more informed food choices. In total, 40 different recipes were considered, focusing on most popular consumer choices in the UK. The estimated impact from ready-made sandwiches ranges from $739 \mathrm{~g} \mathrm{CO}_{2}$ eq. for egg \& cress to $1441 \mathrm{~g}$ $\mathrm{CO}_{2}$ eq. for the bacon, sausage \& egg option. The carbon footprint of the most popular home-made sandwich (ham \& cheese) varies from 399-843 $\mathrm{g} \mathrm{CO}_{2}$ eq. per sandwich, depending on the recipe. The average impact from the home-made option is around two times lower than the impact from the readymade equivalent with the same ingredients. The greatest contributor to the carbon footprint of both types of sandwich is the agricultural production of ingredients; for ready-made sandwiches, the preparation and retail stages are also significant. Various improvement options were considered through 22 scenarios, including changes in the cultivation of ingredients, recipe changes, reduction of food waste, alternative packaging and different waste management options. The findings suggest that reductions in the carbon footprint of up to $50 \%$ are possible for ready-made sandwiches. The greatest improvement opportunities lie in reducing post-consumer waste; however, these are most difficult to realise as they involve changing consumer behaviour.
\end{abstract}

Keywords: carbon footprint, GHG emissions, food, life cycle assessment, lunch, sandwiches

\section{Introduction}

The sandwich has become a ubiquitous convenience food item and today it is difficult to imagine times before its invention. The earliest formal mention of this type of food dates back to 1762, when the English historian Edward Gibbon called the "bits of cold meat" sandwiches, after John Montagu, $4^{\text {th }}$ Earl of Sandwich who preferred to eat his food in this form so that he could continue playing without leaving the gaming-table (Anonymous, 1989). Today, a sandwich is typically defined as a snack food comprising a filling (sweet or savoury) enclosed between two or more slices of bread (IFIS, 2009).

More than 11.5 billion sandwiches are estimated to be consumed in the UK, of which approximately half are prepared at home and the remaining half sold as ready-made and usually pre-packaged (BSA, 2017). Consumer paid $£ 7.85$ billion for the latter, at an average cost of around $£ 2$ per sandwich (BSA, 2017). The most popular ready-made sandwiches include chicken salad bacon, lettuce and tomato (BLT), Ploughman's cheese and egg \& cress (see Table 1). Whereas consumer preference for sandwich fillings fluctuates from year to year, there is a strong preference for the standard sandwich bread: $58 \%$ of sandwiches are made using square slices (BSA, 2010) over non-traditional alternatives such as tortilla wraps, bread rolls or baguettes. With regard to home-made sandwiches, though, consumer surveys indicate that the favourite fillings are ham and cheese (BSA, 2010). This would imply that apart from food left-overs used to prepare lunchbox sandwiches, ham and cheese tend to be the typical ingredients for sandwich making found at home. 
Table 1. Favourite sandwich fillings and types of sandwich in the UK (BSA, 2008; 2010)

\begin{tabular}{lc}
\hline Filling & $\begin{array}{c}\text { Market share } \\
\text { [\%] }\end{array}$ \\
\hline Chicken & 36.6 \\
Ham & 7.6 \\
Cheese & 6.8 \\
Tuna & 5.6 \\
Prawn & 5.1 \\
Bacon & 5.0 \\
Breakfast & 4.7 \\
Cheese & 4.5 \\
Egg & 4.5 \\
Combination & 4.3 \\
Other meats & 4.2 \\
Salmon & 4.1 \\
Salad/vegetables & 2.8 \\
Beef & 2.4 \\
Other fish/seafood & 1.0 \\
\hline
\end{tabular}

\begin{tabular}{lc}
\hline Type of sandwich & $\begin{array}{c}\text { Ranking } \\
\text { (with respect to } \\
\text { popularity) }\end{array}$ \\
\hline Chicken salad & 1 \\
Prawn mayonnaise & 2 \\
Eggs \& cress & 3 \\
Bacon, lettuce \& tomato (BLT) & 4 \\
Mixed selection & 5 \\
Chicken \& bacon & 6 \\
Cheese \& onion & 7 \\
Tuna \& sweetcorn & 8 \\
Cheese Ploughman's & 9 \\
Chicken \& sweetcorn & 10 \\
Salmon \& cucumber & 11 \\
Ham \& mustard & 12 \\
Breakfast & 13 \\
Ham \& Cheddar cheese & 14 \\
Southern fried chicken & 15 \\
Chicken Caesar & 16 \\
Chicken \& stuffing & 17 \\
Egg \& bacon & 18 \\
Tuna \& cucumber & 19 \\
Egg \& mayonnaise & 20 \\
\hline
\end{tabular}

Given that sandwiches are a staple component of the British diet as well as their significant market share in the food sector, it is important to understand the contribution from this sector to the emissions of greenhouse gases. Therefore, the aim of this work is to estimate the carbon footprints of a range of typical UK sandwich varieties, prepared both commercially and at home. The paper also explores how the information on the carbon footprint could be combined with nutritional data to assist consumers in making more informed food choices. As far as the authors are aware, this is the first study of its kind.

\section{Methods}

The methodology used to estimate the carbon footprints of sandwiches follows the ISO 14040/44 (ISO, 2006a; 2006b) and PAS 2050:2011 (BSI, 2011) standards. The following sections discuss the methodological approach, assumptions and data used in the study.

\subsection{Goal of the study}

The main goals of the study are:

- to calculate the GHG emissions arising in the life cycle of most popular ready-made and homemade sandwiches prepared and consumed in the UK; and

- to identify the carbon 'hot spots' and opportunities for improvements.

The functional unit is defined as "one individual sandwich serving, consisting of two slices of bread and a filling, prepared and ready for consumption", representing one serving.

\subsection{Types of sandwich}

Two general types of sandwich are considered: ready-made and home-made; their compositions are detailed in Table 2 to Table 5, based on own market research.

For the commercial ready-made sandwiches, a total of 24 recipes are considered; for details see Table 2-Table 4. These were chosen based on the consumer preferences and also guided by data availability for the ingredients. The recipes are grouped in four categories, depending on the main ingredients: pork meat; chicken meat; fish and prawns; and cheese and eggs (vegetarian). The 
number of ingredients used in each sandwich recipe is relatively small - four on average, with mayonnaise being common to all but two recipes. Other most commonly used ingredients include bacon, ham, cheese and tomato. The mass of the sandwiches ranges from 128 to $199 \mathrm{~g}$, with bread accounting for almost half of the total mass. In turn, the energy content of the sandwiches ranges from 279 up to $546 \mathrm{kcal}(1169-2286 \mathrm{~kJ})$.

For home-made sandwiches, a total of 16 variations on the recipe for ham \& cheese sandwich were considered. The ingredients used in this type of sandwich are assumed to be readily available in any home refrigerator and are ready to be used without any further processing or preparation. In this case, just one recipe was selected because the availability of ingredients at home (including not only fresh ingredients but also food left-overs) combined with the tastes and preferences of the person preparing the sandwich gives rise to a number of potential recipes that cannot be assessed exhaustively within the scope of this study without making too many assumptions. Whereas commercial recipes are standardised, consistency in home-made recipes for sandwiches cannot be assumed to be the norm.

The ingredients considered for home-made ham \& cheese sandwiches are bread, ham, cheese and mayonnaise. The variations in the recipes (Table 5) take into account individual preferences as well as the type/format of ingredients available at home at the time of sandwich preparation (e.g., thin wafer slices of ham or thick slices of bread). In consequence, the mass of the prepared sandwich can vary considerably, ranging from 99 to $190 \mathrm{~g}$. Bread accounts for a significant proportion of the sandwich mass $(43 \%$ to $73 \%)$. The energy content of the sandwiches is similar to that calculated for the commercial sandwiches, ranging from 263 up to $497 \mathrm{kcal}(1102-2081 \mathrm{~kJ})$. The following variations have been considered:

- $\quad$ thickness of bread slices: thin slices $(29 \mathrm{~g})$ or thick slices $(58 \mathrm{~g})$;

- number and thickness of ham slices: one or two slices; a wafer thin slice weighs on average $8 \mathrm{~g}$ and a thin slice weighs on average $12.5 \mathrm{~g}$ (based on products available on the market);

- number of cheese slices: one or two slices; a cheese slice weighs on average $20 \mathrm{~g}$ (based on products available in the market);

- mayonnaise: one tablespoon (13 g).

\subsection{System description}

As indicated in Figure 1 and Figure 2, the system boundaries for both ready- and home-made sandwiches are from 'cradle to grave'. This includes the production of agricultural products and packaging materials, processing of ingredients, preparation of sandwiches, packing of sandwiches, retail at convenience stores (of ready-to-eat sandwiches or ingredients for home-made sandwiches), consumption of sandwiches and disposal of food waste and waste packaging. Once prepared, readymade sandwiches need to be kept in a cold chain up to the retail stage; this requirement is not necessary for sandwiches prepared at home and consumed on the day. Specifically, the following processes are included within the system boundaries:

- cultivation and harvest of cereals and vegetables in the UK assuming conventional agricultural practices;

- rearing of animals (beef cattle, pigs, chicken) and processing of meat in the UK using conventional agricultural practices;

- cultivation of prawns in Scandinavia and fishing of tuna off the Atlantic coast of Spain; sea shipping to the UK;

- $\quad$ production of white bread in the UK, using domestic ingredients;

- production of packaging materials for ingredients (cardboard boxes, plastic trays) and sandwiches (triangular plastic trays for commercial sandwiches; plastic resealable bags for home-made sandwiches consumed away from home);

- ambient/refrigerated storage of ingredients at the commercial sandwich preparation premises and at home;

- operation of commercial sandwich-preparation premises; 
- $\quad$ refrigerated distribution and storage of sandwiches at retailers;

- ambient and refrigerated storage of ingredients for home-made sandwiches at retailers;

- waste management of all waste streams (food, packaging materials) by landfilling;

- transport of all materials and waste within the UK by road, assuming a reference distance of 100 $\mathrm{km}$ in all cases;

- refrigerant losses from refrigerated retail and refrigerated transport of ingredients.

Following PAS 2050 (BSI, 2011), the following processes are excluded from consideration:

- the construction of facilities and manufacture of equipment;

- human energy inputs; and

- the transport of consumers to and from the point of retail.

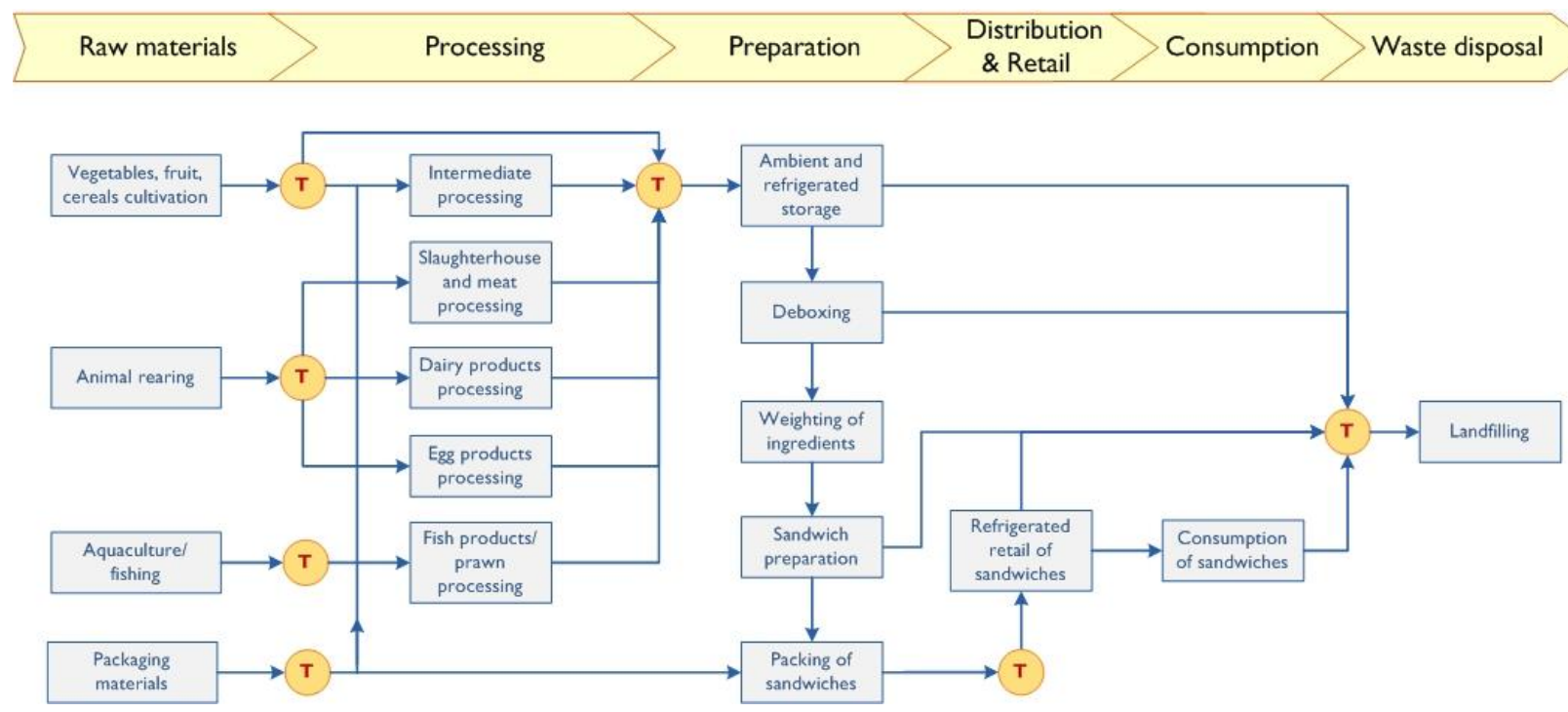

Figure 1. System boundary for commercial ready-made sandwiches [ $\mathrm{T}$ - transport]

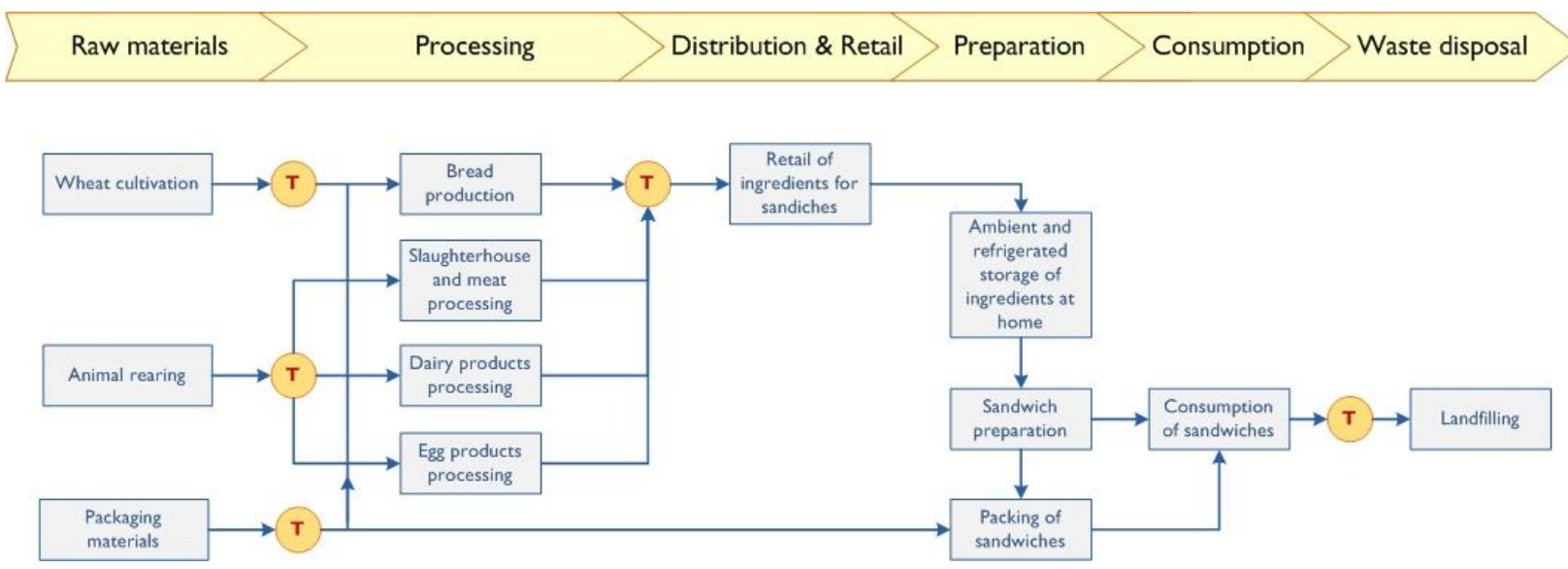

Figure 2. System boundary for home-made ham \& cheese sandwiches [ $T$ - transport] 
Table 2. Ingredients for typical commercially-prepared sandwiches based on one serving: recipes containing pork meat

\begin{tabular}{|c|c|c|c|c|c|c|c|c|c|c|c|c|c|c|c|}
\hline No. & Sandwich type & 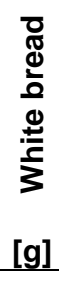 & $\begin{array}{l}\frac{\varepsilon}{\widetilde{T}} \\
{[\mathrm{~g}]}\end{array}$ & 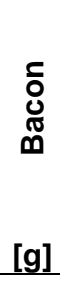 & 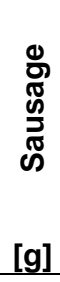 & $\begin{array}{l}\text { 옴 } \\
\text { 요 } \\
\text { [g] }\end{array}$ & 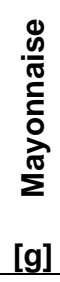 & 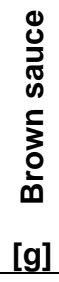 & 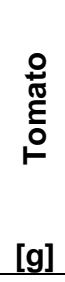 & 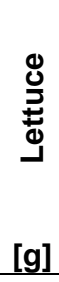 & 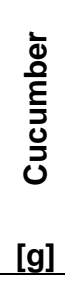 & 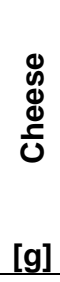 & $\begin{array}{l}\frac{0}{x} \\
\frac{0}{a} \\
{[g]}\end{array}$ & Total mass & $\begin{array}{c}\begin{array}{c}\text { Energy } \\
\text { content }\end{array} \\
\text { [kcal] }\end{array}$ \\
\hline 1 & Breakfast & 80 & - & 19 & 39 & 47 & 11 & - & - & - & - & - & - & 196 & 546 \\
\hline 2 & $\begin{array}{l}\text { Bacon, lettuce and } \\
\text { tomato }(B L T)\end{array}$ & 80 & - & 28 & - & - & 19 & - & 27 & 17 & - & - & - & 171 & 415 \\
\hline 3 & Egg and bacon & 80 & - & 24 & - & 78 & 17 & - & - & - & - & - & - & 199 & 503 \\
\hline 4 & Ham salad & 80 & 38 & - & - & - & 15 & - & 13 & 18 & 13 & - & - & 177 & 299 \\
\hline 5 & Ham and cheese & 80 & 38 & - & - & - & 16 & - & - & - & - & 30 & - & 164 & 415 \\
\hline 6 & Ham and egg & 80 & 29 & - & - & 23 & 4 & - & - & - & - & - & - & 137 & 294 \\
\hline 7 & $\begin{array}{l}\text { Ham and } \\
\text { mayonnaise }\end{array}$ & 80 & 39 & - & - & - & 9 & - & - & - & - & - & - & 128 & 279 \\
\hline 8 & Ham and mustard & 80 & 39 & - & - & - & 14 & - & - & - & - & - & 6 & 139 & 291 \\
\hline 9 & $\begin{array}{l}\text { Sausage and } \\
\text { brown sauce }\end{array}$ & 80 & - & - & 49 & - & - & 15 & - & - & - & - & - & 144 & 391 \\
\hline
\end{tabular}


Table 3. Ingredients for typical commercially-prepared sandwiches based on one serving: recipes containing chicken meat, prawn and tuna.

\begin{tabular}{|c|c|c|c|c|c|c|c|c|c|c|c|c|c|c|}
\hline No. & Sandwich type & 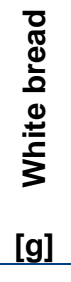 & 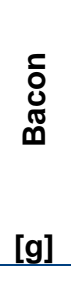 & $\begin{array}{l}\frac{c}{d} \\
\frac{\grave{d}}{\frac{D}{\delta}} \\
\frac{0}{0} \\
{[\mathrm{~g}]}\end{array}$ & 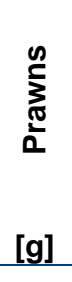 & $\begin{array}{l}\stackrel{\mathbb{2}}{5} \\
{[g]}\end{array}$ & 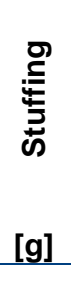 & 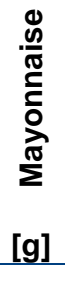 & $\begin{array}{l}\stackrel{0}{\mathbb{\pi}} \\
\stackrel{\text { E⿱ }}{0} \\
\text { [g] }\end{array}$ & 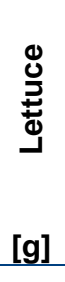 & 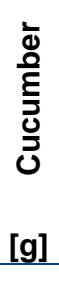 & 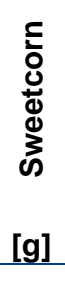 & Total mass & $\begin{array}{c}\begin{array}{c}\text { Energy } \\
\text { content }\end{array} \\
\text { [kcal] }\end{array}$ \\
\hline 1 & Chicken salad & 80 & - & 49 & - & - & - & 22 & 16 & 16 & 10 & - & 193 & 351 \\
\hline 2 & $\begin{array}{l}\text { Roast chicken and } \\
\text { bacon }\end{array}$ & 80 & 18 & 33 & - & - & - & 19 & - & - & 27 & - & 177 & 413 \\
\hline 3 & $\begin{array}{l}\text { Roast chicken and } \\
\text { stuffing }\end{array}$ & 80 & - & 45 & - & - & 16 & 16 & - & - & - & - & 157 & 372 \\
\hline 4 & $\begin{array}{l}\text { Chicken and } \\
\text { sweetcorn }\end{array}$ & 80 & - & 43 & - & - & - & 9 & - & - & - & 17 & 149 & 321 \\
\hline 5 & $\begin{array}{l}\text { Chicken and } \\
\text { mayonnaise }\end{array}$ & 80 & - & 59 & - & - & - & 19 & - & - & - & - & 158 & 354 \\
\hline 6 & $\begin{array}{l}\text { Prawn and } \\
\text { mayonnaise }\end{array}$ & 80 & - & - & 50 & - & - & 29 & - & - & - & - & 159 & 339 \\
\hline 7 & $\begin{array}{l}\text { Tuna and } \\
\text { sweetcorn }\end{array}$ & 80 & - & - & - & 41 & - & 22 & - & - & - & 26 & 169 & 336 \\
\hline 8 & $\begin{array}{l}\text { Tuna and } \\
\text { cucumber }\end{array}$ & 80 & - & - & - & 47 & - & 21 & - & - & 25 & - & 173 & 320 \\
\hline
\end{tabular}


Table 4. Ingredients for typical commercially-prepared sandwiches based on one serving: vegetarian recipes containing egg and cheese.

\begin{tabular}{|c|c|c|c|c|c|c|c|c|c|c|c|c|c|c|}
\hline No. & Sandwich type & 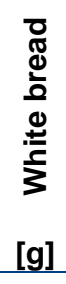 & $\begin{array}{l}\stackrel{9}{\circ} \\
\text { 묘 } \\
\text { [g] }\end{array}$ & 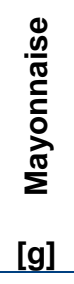 & $\begin{array}{l}\stackrel{0}{0} \\
\stackrel{0}{0} \\
\text { है } \\
\vdash \\
\text { [g] }\end{array}$ & 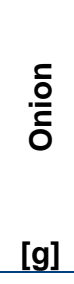 & 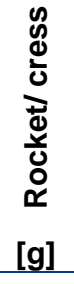 & $\begin{array}{l}\frac{\pi}{0} \\
0 \\
\text { [g] }\end{array}$ & $\begin{array}{l}\frac{0}{\circ} \\
\frac{0}{\alpha} \\
\text { [g] }\end{array}$ & 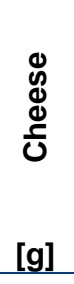 & $\begin{array}{l}\varepsilon \\
\mathbb{\Xi} \\
\stackrel{d}{U} \\
{[g]}\end{array}$ & $\begin{array}{l}\frac{0}{\frac{x}{0}} \\
\frac{0}{a} \\
{[g]}\end{array}$ & Total mass & $\begin{array}{c}\text { Energy } \\
\text { content } \\
\text { [kcal] }\end{array}$ \\
\hline 1 & $\begin{array}{l}\text { Ploughman's } \\
\text { cheese }\end{array}$ & 80 & - & 15 & 33 & 3 & - & 4 & 4 & 40 & - & 20 & 199 & 421 \\
\hline 2 & $\begin{array}{l}\text { Cheese and } \\
\text { mayonnaise }\end{array}$ & 80 & - & 10 & - & - & - & - & - & 40 & - & - & 130 & 397 \\
\hline 3 & Cheese and pickle & 80 & - & - & - & - & - & - & - & 40 & - & 14 & 134 & 376 \\
\hline 4 & $\begin{array}{l}\text { Cheese and } \\
\text { tomato }\end{array}$ & 80 & - & 8 & 34 & - & - & - & - & 39 & - & - & 162 & 399 \\
\hline 5 & Cheese and onion & 80 & - & 29 & - & 12 & - & - & - & 41 & 3 & - & 171 & 455 \\
\hline 6 & $\begin{array}{l}\text { Egg mayonnaise } \\
\text { and cress }\end{array}$ & 80 & 51 & 11 & - & - & 5 & - & - & - & - & - & 147 & 319 \\
\hline 7 & Egg and rocket & 80 & 72 & 16 & - & - & 5 & - & - & - & - & - & 173 & 363 \\
\hline
\end{tabular}


Accepted for publication in Sustainable Production and Consumption:

https://doi.org/10.1016/j.spc.2017.12.002

Table 5. Ingredients for home-made sandwiches based on one serving

\begin{tabular}{ccccccc}
\hline Recipe & $\begin{array}{c}\text { White bread } \\
{[\mathbf{g}]}\end{array}$ & $\begin{array}{c}\text { Ham } \\
{[\mathbf{g}]}\end{array}$ & $\begin{array}{c}\text { Cheese } \\
{[\mathbf{g}]}\end{array}$ & $\begin{array}{c}\text { Mayonnaise } \\
{[\mathbf{g}]}\end{array}$ & $\begin{array}{c}\text { Total mass } \\
{[\mathbf{g}]}\end{array}$ & $\begin{array}{c}\text { Energy content } \\
{[\mathrm{kcal}]}\end{array}$ \\
\hline 1 & 58 & 8 & 20 & 13 & 99.0 & 274 \\
2 & 58 & 8 & 40 & 13 & 119.0 & 355 \\
3 & 58 & 16 & 20 & 13 & 107.0 & 284 \\
4 & 58 & 16 & 40 & 13 & 127.0 & 364 \\
5 & 58 & 13 & 20 & 13 & 103.5 & 280 \\
6 & 58 & 13 & 40 & 13 & 123.5 & 360 \\
7 & 58 & 25 & 20 & 13 & 116.0 & 294 \\
8 & 58 & 25 & 40 & 13 & 136.0 & 375 \\
9 & 112 & 8 & 20 & 13 & 153.0 & 418 \\
10 & 112 & 8 & 40 & 13 & 173.0 & 499 \\
11 & 112 & 16 & 20 & 13 & 161.0 & 427 \\
12 & 112 & 16 & 40 & 13 & 181.0 & 508 \\
13 & 112 & 13 & 20 & 13 & 157.5 & 423 \\
14 & 112 & 13 & 40 & 13 & 177.5 & 504 \\
15 & 112 & 25 & 20 & 13 & 170.0 & 439 \\
16 & 112 & 25 & 40 & 13 & 190.0 & 518 \\
\hline
\end{tabular}

\subsection{Assumptions and data}

The summary of the assumptions and data sources be found in Table 6 and Table 7, respectively.

Sandwiches fall into the category of high-risk food as they are products intended for consumption either cold or heated but without further cooking. As such, they are capable of supporting pathogenic bacterial growth (e.g. Salmonella, Listeria) and, if contaminated, there is a potential for causing food poisoning (BSA, 2007). Safe and hygienic sandwich preparation entails the implementation of standardised protocols and the maintenance of a cold chain, whereby ingredients and prepared sandwiches are constantly kept under refrigerated conditions at chilling temperatures $\left(\leq 5^{\circ} \mathrm{C}\right.$, required and monitored by UK retailers (Goodburn, 2010$) ; \leq 8^{\circ} \mathrm{C}$ required legally (HMSO, 2006)). These considerations, along with $\mathrm{HACCP}^{1}$ plans prepared for each type of sandwich, assist manufacturers and food authorities in determining the shelf life of the final products. The intrinsic characteristics of this type of convenience food product - short shelf life, complex and uncertain demand forecasts, just-in-time inventory management for ingredients, stocking policies of retailers, demand variability depending on consumer preferences, weather, seasonality, public holidays and public events and short lead times for orders - determine the dynamic nature of the commercial sandwich supply chain. Hence, for hygienic, safety and logistics reasons ready-to-eat sandwiches have a very short shelf life in the UK - only two days (Goodburn, 2010).

1 HACCP (Hazards Analysis and Critical Control Points) is an international food safety management system for minimising health risks along the food chain. 
Therefore, for the purposes of this study, it was assumed that once purchased, all perishable sandwich ingredients (prepared and cold meats, vegetables, cheese) - for ready- and homemade sandwiches - are stored under refrigerated conditions for a maximum of 24 hours. Bread, on the other hand, is assumed to be stored at ambient temperature. It was also assumed that commercial sandwiches are prepared freshly on a daily basis and delivered under refrigerated conditions directly from the manufacturer to the retail outlets on the same day, thus bypassing regional distribution centres.

It is imperative to ensure that the refrigerated retail cabinets are fully stocked with sandwiches by the time the shops open. Delays in delivery and stocking lead to missed sales opportunities and the consequent generation of food waste from unsold products and products past their shelf life. To assess the storage of sandwiches at the retail shops, it was assumed that they were stocked for a period of two days in a refrigerated cabinet with dimensions of $1 \mathrm{~m}$ width, $1 \mathrm{~m}$ depth and $1.7 \mathrm{~m}$ height; and a total display area (TDA) of $1.3 \mathrm{~m}^{2}$, calculated according to ISO 23953-2 (BSI, 2005). The cabinet has a storage capacity of 195 sandwiches, distributed between five trays, and in three rows of 13 sandwiches each (based on observation of sandwich cabinets available at retail shops in UK).

Packaging used for commercial sandwiches in the UK is a characteristic triangularly-shaped container, either made of plastic, cardboard or a combination of both, where the two halves of a square-shaped sandwich cut diagonally are placed side by side (see Figure 3). In this study, it was assumed that the sandwiches were packaged in plastic containers (PET) weighing $11 \mathrm{~g}$ (based on own measurements of packaging available on the market). For home-made lunchbox sandwiches, it was assumed that they were packed in a resealable plastic bag (LDPE) weighing $3 \mathrm{~g}$ (based on own measurements of sandwich bags available in the market).

Using data reported by Bartlett (2010) and WRAP (2010a) for waste generated in the food and drinks industry as well as the food supply chain in the UK, it was estimated that the material throughput equivalent to 1.205 sandwiches is required to produce a sandwich that is actually sold in a shop. This is due to food waste generated at the preparation stage (3.3\%), oversupply to satisfy variable demand (6.5\%), distribution losses (0.7\%) and retail losses and unsold products $(10 \%)$. In line with the data reported by WRAP (2008) for food waste by consumers, it was assumed that one third of both ready- and home-made sandwiches were not consumed.
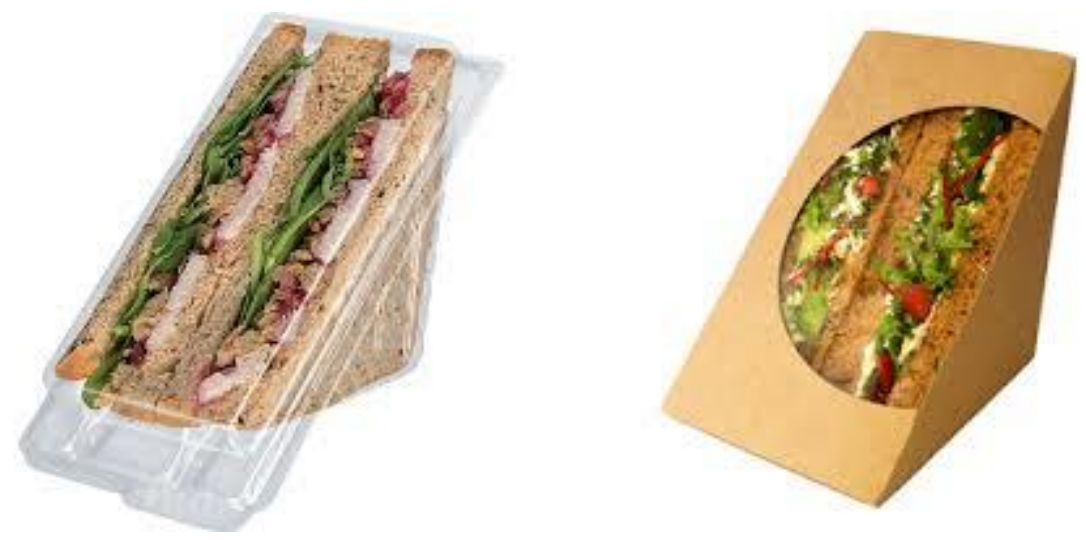

Figure 3 Typical plastic and cardboard packaging and the triangular shape of ready-made sandwiches in the UK 
Table 6. Summary of assumptions

\begin{tabular}{|c|c|c|}
\hline Activity/Category & Commercial sandwiches & Home-made sandwiches \\
\hline $\begin{array}{l}\text { Cultivation of crops and rearing of } \\
\text { animals }\end{array}$ & UK, conventional agricultural practices & $\begin{array}{l}\text { UK, conventional agricultural } \\
\text { practices }\end{array}$ \\
\hline Greenhouses for tomato cultivation & $\begin{array}{l}\text { Natural gas and electricity used for heating } \\
\text { and lighting of greenhouses }\end{array}$ & \\
\hline Greenhouses for lettuce cultivation & Natural gas used for heating of greenhouses & \\
\hline Prawns and refrigerated transport & Denmark, $500 \mathrm{~km}$ by road/sea & \\
\hline Tuna fishing and processing & $\begin{array}{l}\text { Off Atlantic coast of Spain; processing and } \\
\text { canning in mainland Spain. }\end{array}$ & \\
\hline Packaging materials for ingredients & $\begin{array}{l}\text { Vegetables and processed meats packed in } \\
\text { plastic bags and reusable plastic trays; tin } \\
\text { plated cans used for tuna; plastic bags for } \\
\text { bread; plastic containers for sauces. }\end{array}$ & $\begin{array}{l}\text { Plastic trays for ham, cheese; } \\
\text { plastic container for } \\
\text { mayonnaise; plastic bags for } \\
\text { bread. }\end{array}$ \\
\hline Packaging materials for sandwiches & Plastic tray (PET): $7 \mathrm{~g}$; plastic film (PET): $2 \mathrm{~g}$ & $\begin{array}{l}\text { Plastic resealable bag (LDPE): } \\
3 \mathrm{~g}\end{array}$ \\
\hline Ambient storage of ingredients & 1 day & 1 day \\
\hline Refrigerated storage of ingredients & 1 day & 1 day \\
\hline Refrigerated storage of sandwiches & 2 days at $\leq 8^{\circ} \mathrm{C}$ & 1 day at $\leq 8^{\circ} \mathrm{C}$ \\
\hline Operation of retail premises & $\begin{array}{l}\text { Electricity used for lighting, ventilation and } \\
\text { cabinet operation; natural gas used for heating. }\end{array}$ & \\
\hline Food waste during sandwich & $3.3 \%$ of food waste & None \\
\hline preparation & $6.5 \%$ oversupply & \\
\hline $\begin{array}{l}\text { Food waste during distribution of } \\
\text { sandwiches }\end{array}$ & $0.7 \%$ & \\
\hline Retail sandwich waste & $10 \%$ & \\
\hline Post-consumer sandwich waste & $33 \%$ & $33 \%$ \\
\hline $\begin{array}{l}\text { Waste management of all waste } \\
\text { streams }\end{array}$ & Landfilling & Landfilling \\
\hline Transport within the UK & $100 \mathrm{~km}$ by road transport & \\
\hline Refrigerant losses & $\begin{array}{l}1 \% \text { uplift of overall GHG emissions to account } \\
\text { for losses at manufacturing facilities; } 10 \% \text { for } \\
\text { refrigerated distribution; } 15 \% \text { for refrigerated } \\
\text { retail; refrigerant R404A. }\end{array}$ & Not considered. \\
\hline
\end{tabular}

\section{Table 7. Sources of life cycle inventory data}

\begin{tabular}{ll}
\hline Data set & Source \\
\hline Bread production & Espinoza-Orias et al. (2011) \\
Cultivation of lettuce in the UK & Hospido et al. (2009) \\
Cultivation of tomato in the UK & Williams et al. (2006) \\
Cultivation of cucumber, onion, celery, corn, apples in the UK & DEFRA (2009a) \\
Production of eggs, chicken meat, pork meat, cheese in the UK & DEFRA (2009a) \\
Processing of ham, bacon, sausages & JRC (2006) \\
Production of canned tuna & Hospido et al. (2006) \\
Production of prawns & Nielsen et al (2003) \\
Production of sauces (mayonnaise, brown sauce) & Unilever (2010); Kikkoman (2009) \\
Refrigerated transport, storage and retail & DEFRA (2009b) \\
Production of packaging materials (plastic and cardboard) & Ecoinvent (2010) \\
Landfilling of waste & DEFRA/DECC (2010) \\
Road transport & Ecoinvent (2010) \\
\hline
\end{tabular}

\section{Results and discussion}

The results for the ready-made sandwiches are presented in Figure 4-Figure 7, grouped according to the type of meat used (pork, chicken, seafood) or the lack thereof (vegetarian). Figure 8 shows the results for the home-made sandwiches; these are discussed in turn below. Note that the life cycle stages shown in the legend of each figure comprise the following activities: 
- ingredients: cultivation of crops, post-harvest and preliminary processing of crops and vegetables, rearing of animals, processing of animal products (cheese and meats);

- preparation: assembly of sandwiches;

- retail: refrigerated retail of commercial sandwiches, retail of ingredients for home-made sandwiches and operation of retail premises;

- packaging: production of packaging for ingredients and sandwiches;

- waste management: landfilling of packaging materials and food waste; and

- transport: transport of ingredients, packaging materials, sandwiches and waste.

\subsection{Carbon footprint of ready-made sandwiches}

As can be seen from Figure 4-Figure 7, the carbon footprint of different types of sandwich considered here ranges from $739 \mathrm{~g} \mathrm{CO}_{2}$ eq. for the egg \& cress sandwich to $1441 \mathrm{~g} \mathrm{CO}_{2}$ eq. for the breakfast recipe. Overall, the highest carbon footprints (>1200 g CO 2 eq.) are for the sandwiches with a combination of pork meat (bacon, ham or sausages), cheese and prawns. Sandwiches containing chicken and tuna have the carbon footprint in the range of 769-1258 g $\mathrm{CO}_{2}$ eq. while that of the vegetarian sandwiches ranges from 739-1112 $\mathrm{g} \mathrm{CO}_{2}$ eq. The inclusion of cheese in the vegetarian recipes results in the carbon footprints comparable to or even higher than for some of the meat sandwiches. For example, cheese Ploughman's emits $1112 \mathrm{~g} \mathrm{CO}_{2}$ eq. while chicken \& bacon produces $1083 \mathrm{~g} \mathrm{CO}_{2}$ eq. per serving. This is largely due to the higher carbon footprint of cheese than chicken or bacon.

In all cases, the production of ingredients contributes most to the total carbon footprint (37.3$67.1 \%$ ). The contributions of sandwich preparation and refrigerated retail vary between 13.1$24.6 \%$ and $12.4-24.2 \%$, respectively. Packaging contributes $4.3 \%$ to $8.5 \%$ and transport $2.2 \%$ to $4.3 \%$; the contribution from waste management is negligible $(0.8-1.3 \%)$.

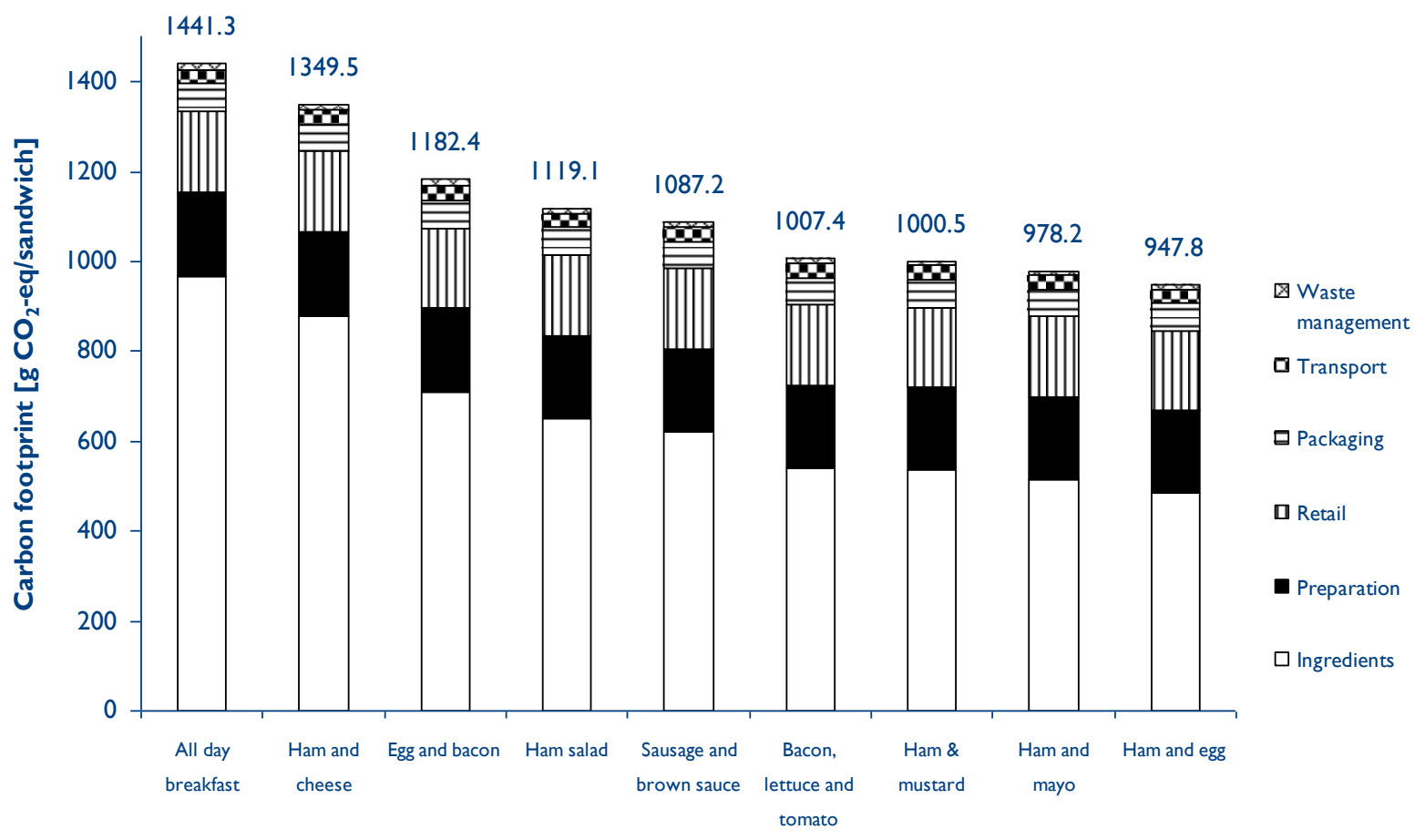

Figure 4. Carbon footprint of ready-made sandwiches containing pork meat 
Accepted for publication in Sustainable Production and Consumption:

https://doi.org/10.1016/j.spc.2017.12.002

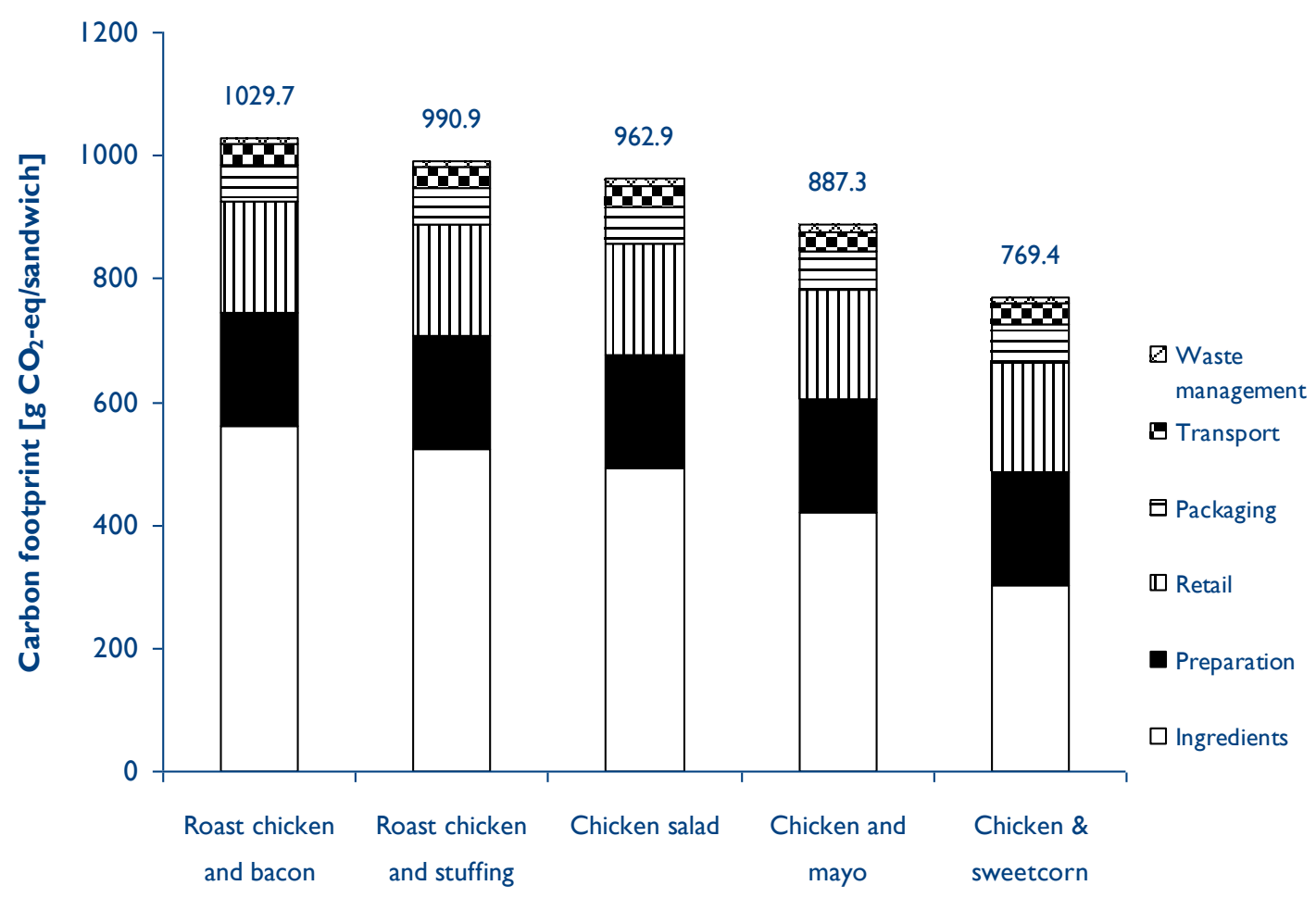

Figure 5. Carbon footprint of ready-made sandwiches containing chicken meat

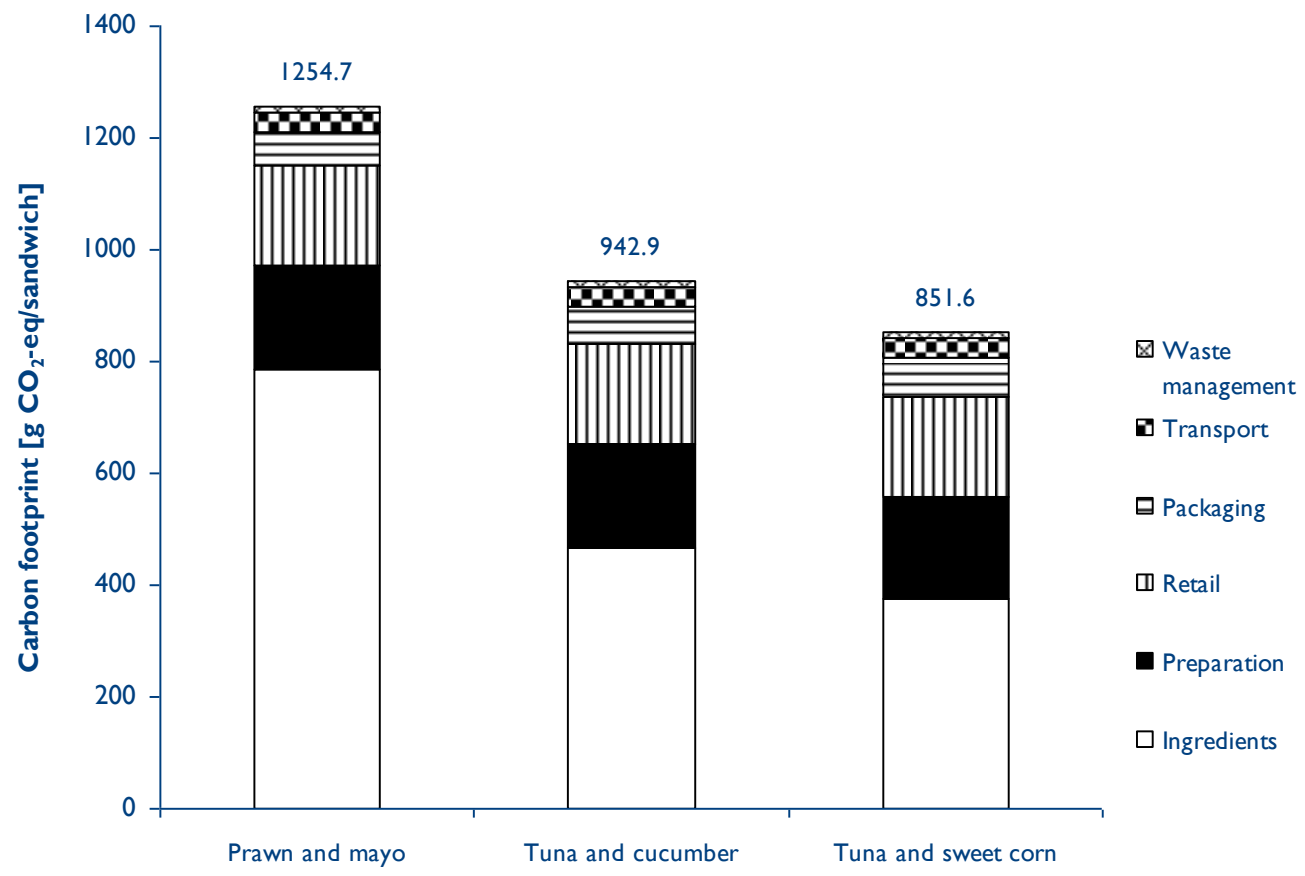

Figure 6. Carbon footprint of ready-made sandwiches containing seafood 
Accepted for publication in Sustainable Production and Consumption:

https://doi.org/10.1016/j.spc.2017.12.002

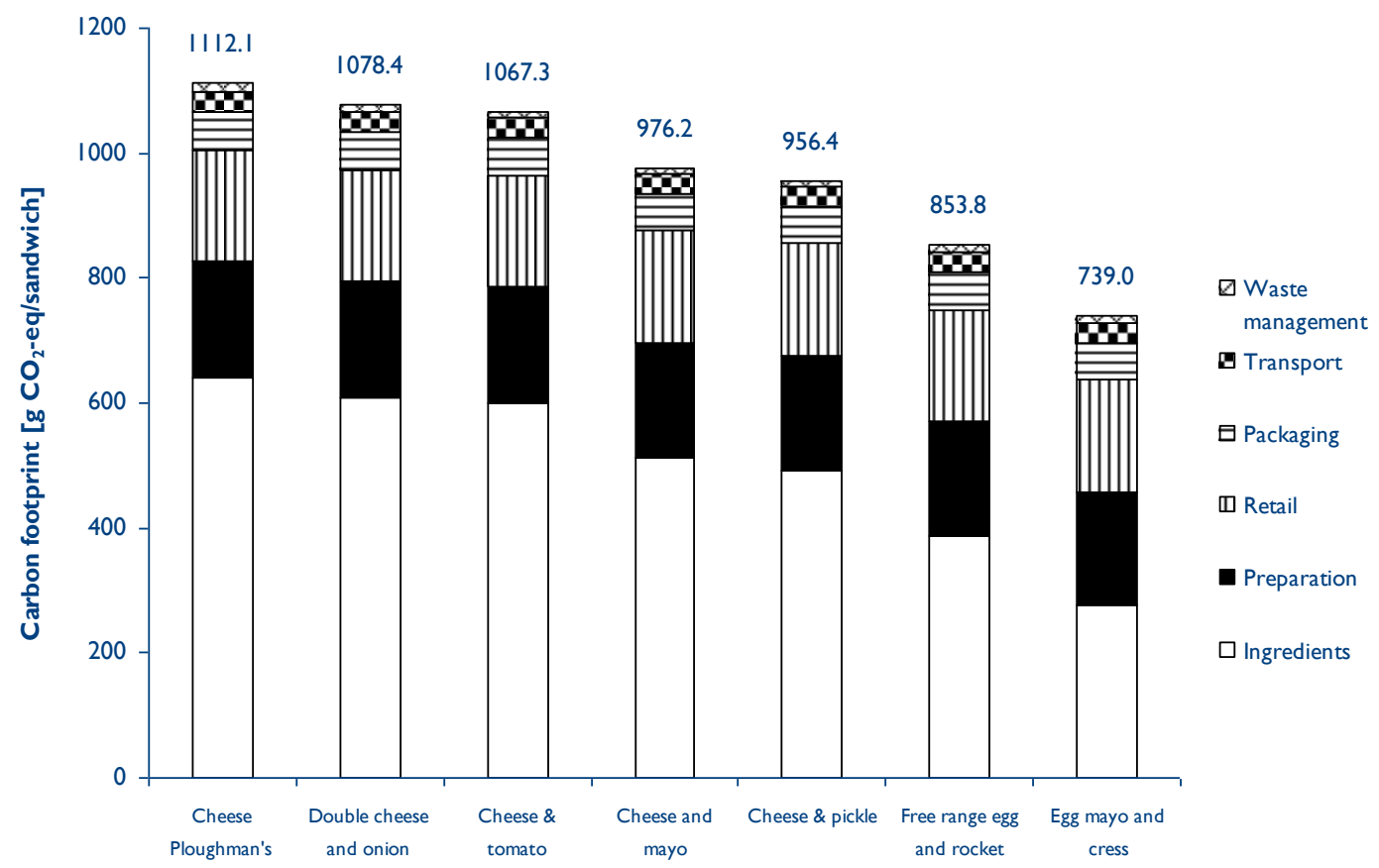

Figure 7. Carbon footprint of vegetarian ready-made sandwiches

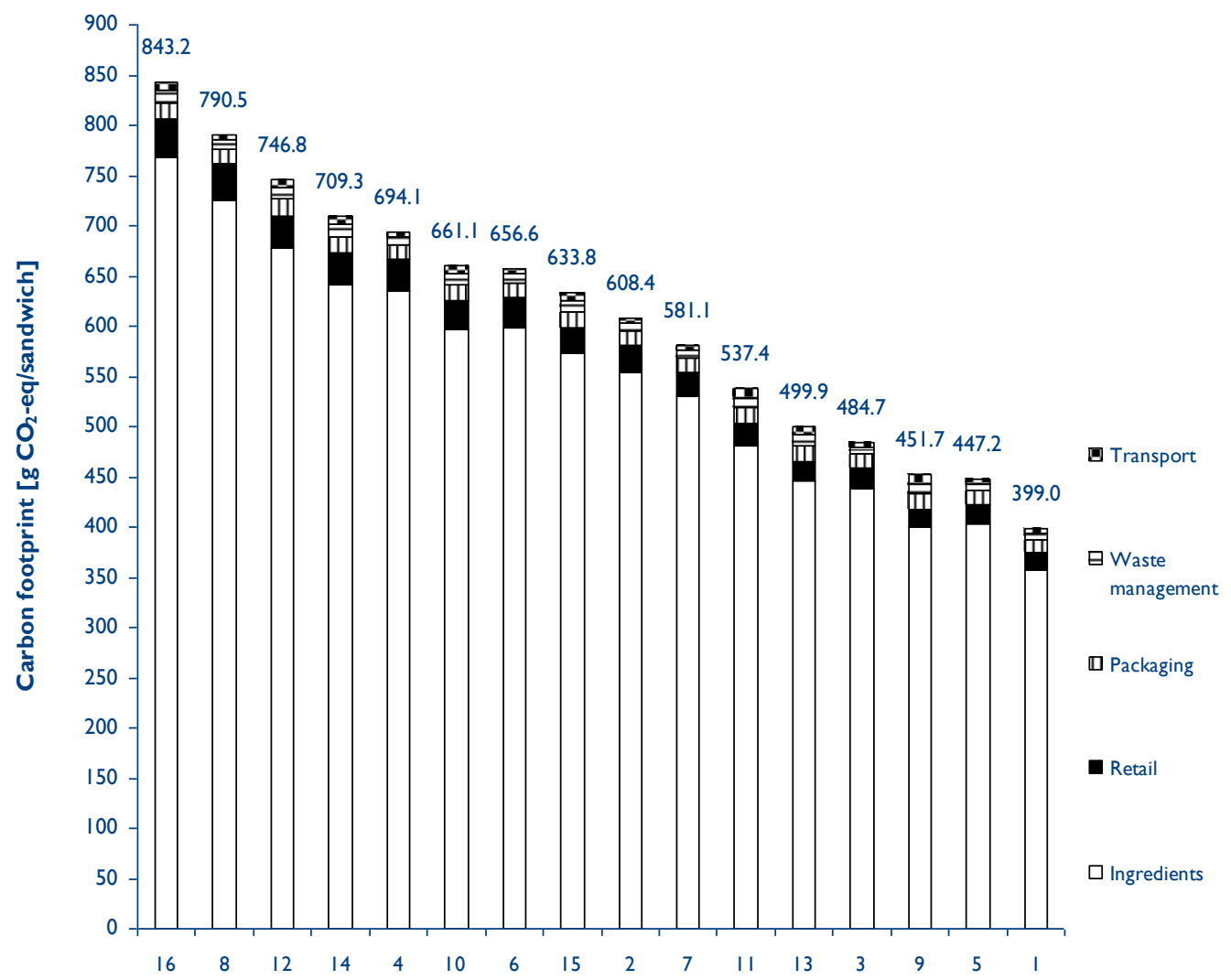

Figure 8. Carbon footprint of home-made sandwiches

(The numbers on the $\mathrm{x}$-axis correspond to the sandwich recipes given in Table 5). 
It is also interesting to explore if there is a correlation between the carbon footprint, mass and energy content of the sandwiches. These results are shown in Figure 9, from which it is apparent that there is no discernible relationship between the values of these parameters.

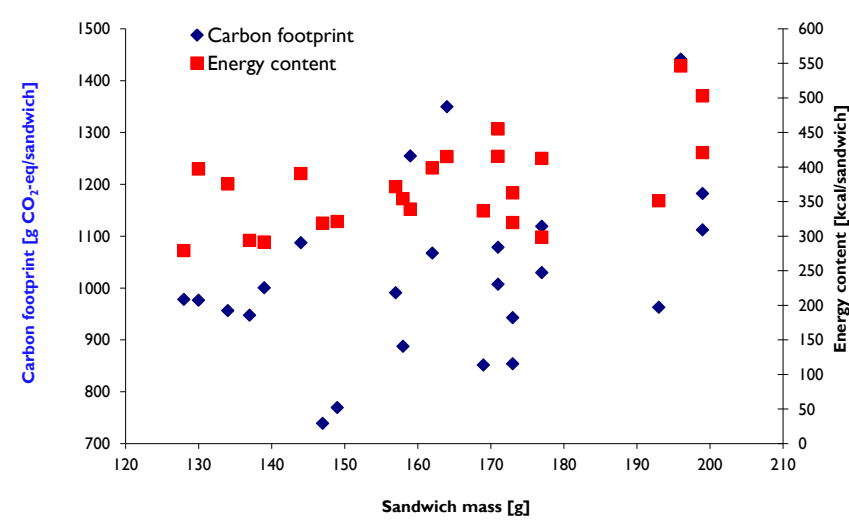

a)

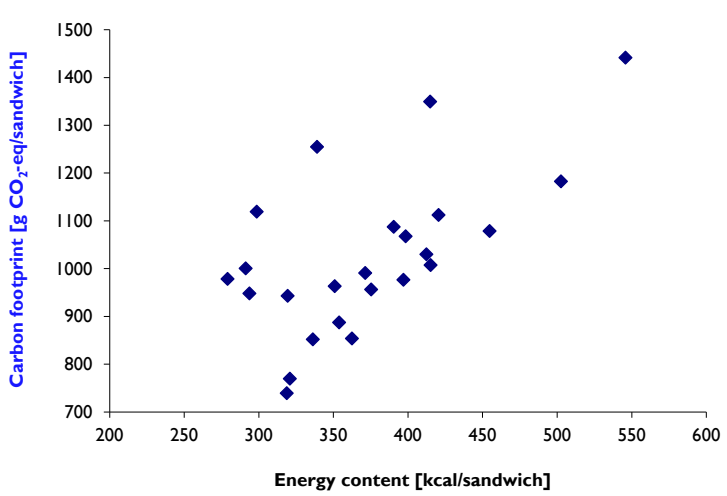

b)

Figure 9. Relationship between the carbon footprint, mass and energy content of readymade sandwiches

Another aspect worth exploring is that sandwiches are often offered by retailers as part of a competitively priced 'meal deal', which in addition to a sandwich usually includes a pack of crisps and a soft drink. This encourages consumers to purchase these additional products, which would not necessarily be consumed with a sandwich. Therefore, to put the results for the sandwiches in a wider context, the carbon footprint of the 'meal deal' was also estimated. The data for the typical additional components of the 'meal deal' are summarised in Table 8 . Using the results for the sandwiches presented in the previous section and the data in Table 8, the carbon footprint of a meal deal is estimated at 989-1761 $\mathrm{g} \mathrm{CO}_{2}$ eq. per meal. In this case, the sandwich contributes $69.8-85.2 \%$ to the total impact of the 'meal deal', the drink $10.1-22.7 \%$ and the packet of potato crisps $4.5-8.1 \%$. Thus, arguably, the carbon footprint of the sandwich increases by $18 \%-24 \%$ due to the 'meal deal' promotion.

\section{Table 8. Carbon footprint of the products included in the 'meal deal'}

\begin{tabular}{lcl}
\hline Product & $\begin{array}{c}\text { Carbon footprint } \\
\text { [g CO } \mathbf{~ C q}_{\mathbf{2}} \text {./unit] }\end{array}$ & Source \\
\hline Ready-made sandwich & $739-1441$ & This study \\
Potato crisps, 34.5 g pack & 80 & Walkers (2009) \\
Coca Cola, $330 \mathrm{ml}$, Al can & 170 & Coca Cola (2017) \\
Coca Cola, $500 \mathrm{ml}$, PET bottle & 240 & Coca Cola (2017) \\
Fruit smoothie (strawberry \& banana), $250 \mathrm{ml}$, PET bottle & 230 & Innocent (2009) \\
Total & $\mathbf{9 8 9 - 1 7 6 1 ^ { \text { a } }}$ & \\
\hline
\end{tabular}

a The lower value corresponds to the minimum carbon footprint of the sandwich and soft drink and the higher value to the maximum carbon footprint of these two products.

\subsection{Carbon footprint of home-made sandwiches}

The carbon footprint of home-made sandwiches ranges between 399-843 g CO 2 eq./sandwich (Figure 8). The results are largely proportional to the amount of ingredients used - the lightest sandwich weighs $99 \mathrm{~g}$ and has the lowest carbon footprint of $399 \mathrm{~g} \mathrm{CO}_{2}$ eq. while the heaviest sandwich weighs $190 \mathrm{~g}$ and has the highest carbon footprint of $843 \mathrm{~g} \mathrm{CO}_{2}$ eq. However, as shown in Figure 10a, the relationship with the total mass of sandwiches and the carbon footprint is bi-modal, with the results following two distinct trends. This is largely due to the use of thin 
(the first trend line on the left side in the figure) and thick (second trend line) slices of bread, the latter of which has almost twice the mass of the former (112 g vs $58 \mathrm{~g}$ ). The relationship between the energy content and the sandwich mass also shows a better proportionality than that for the ready-made sandwiches (Figure 10a). However, like ready-made products, there is no relationship between the carbon footprint and the energy content (Figure 10b).

Similar to the ready-made sandwiches, the production of ingredients is the main carbon hot spot, contributing between $88.6-91.9 \%$ to the total impact. The next highest contribution is from the retail of ingredients $(3.9 \%-4.6 \%)$, followed by packaging $(1.8 \%-3.5 \%)$. The contribution from waste management and transport is small $(1.1-2.2 \%$ and $0.7-1.8 \%$, respectively) and that of refrigerated storage of ingredients negligible $(<0.001 \%)$.

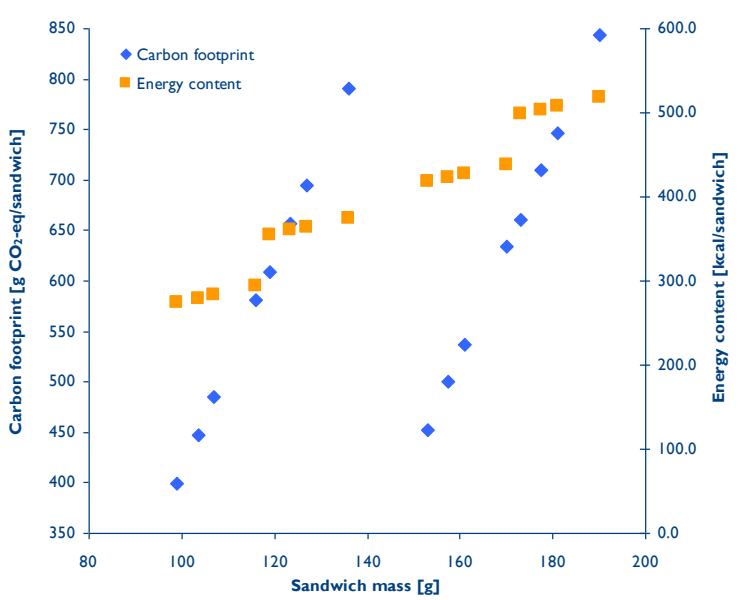

a)

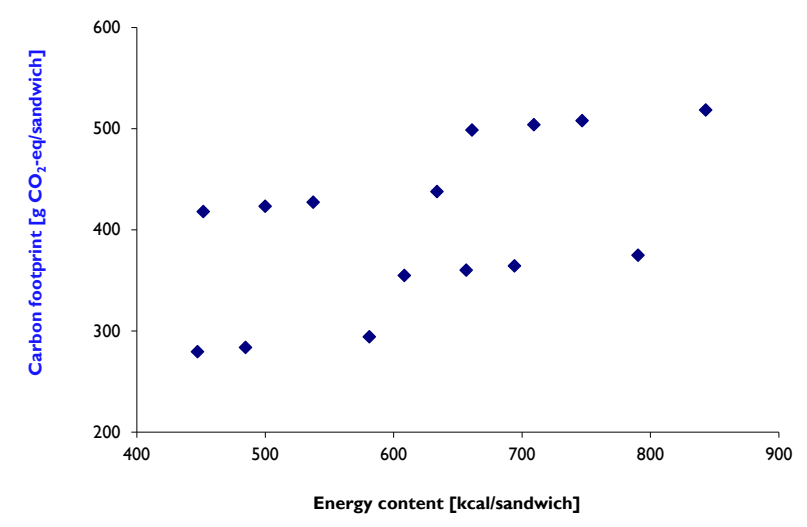

b)

Figure 10. Relationship between the carbon footprint, mass and energy content of homemade sandwiches

[a) The blue trend line on the left denotes the carbon footprint-sandwich mass relationship for thin bread slices (58 $\mathrm{g}$ ) and the blue trend line on the right corresponds to thick slices $(112 \mathrm{~g})$. For the recipes, see Table 5.]

\subsection{Comparison of ready-made and home-made sandwiches}

The results suggest that, in general, home-made sandwiches have a lower carbon footprint than commercial sandwiches, for the recipes considered here. This is mainly due to:

- Resource use: Food losses along the supply chain of commercial sandwiches imply that $20.5 \%$ more ingredients are actually required to deliver one sandwich at the retail stage.

- Preparation: Even though the preparation of commercial sandwiches does not entail the processing or manufacturing of the ingredients, energy is still required for the refrigerated storage facilities for the ingredients and finalised products as well as the operation of the sandwich assembly line. The additional impact is due to the leakage of refrigerants. On the other hand, the preparation of sandwiches at home using ready-to-eat ingredients uses a minimal amount of energy (refrigerated storage) and there is no leakage of refrigerant.

- Post-preparation handling: Once prepared, ready-made sandwiches must be kept within the cold chain to ensure their safety up to the retail stage. Home-made sandwiches, on the other hand, can be consumed promptly after preparation and are usually kept at ambient conditions if not consumed immediately.

More detailed comparisons can be drawn between the ham \& cheese sandwiches prepared commercially and at home due to the similarity of the ingredients, despite slightly different 
recipes (see Table 9). As shown in Table 10, the ready-made product has a much higher carbon footprint (1349.5 $\mathrm{g} \mathrm{CO}_{2}$ eq.) than the home-made version (399-843.2 $\mathrm{g} \mathrm{CO}_{2}$ eq.). In addition to the difference in the recipes, this is largely due to the higher amount of waste in the supply chain, energy used for preparation of sandwiches and in the cold chain, together with the leakage of the refrigerant. This is indicated by the much higher contributions of the preparation $(13.9 \%)$ and retail stages $(13.3 \%)$ for the ready-made sandwich than the home option (Table 10).

Table 9. Comparison of ham \& cheese sandwich recipes (commercial and home-made)

\begin{tabular}{lccccc}
\hline $\begin{array}{l}\text { Type of } \\
\text { sandwich }\end{array}$ & $\begin{array}{c}\text { Bread } \\
{[\mathbf{g}]}\end{array}$ & $\begin{array}{c}\text { Ham } \\
{[\mathbf{g}]}\end{array}$ & $\begin{array}{c}\text { Cheese } \\
{[\mathbf{g}]}\end{array}$ & $\begin{array}{c}\text { Mayonnaise } \\
{[\mathbf{g}]}\end{array}$ & $\begin{array}{c}\text { Total mass } \\
{[\mathrm{g}]}\end{array}$ \\
\hline Ready-made & 80 & 38 & 30 & 16 & 164 \\
Home-made & $58-112$ & $8-25$ & $20-40$ & 13 & $99-190$ \\
\hline
\end{tabular}

Table 10. The carbon footprints of commercial and home-made ham \& cheese sandwiches

\begin{tabular}{cccccccc}
\hline $\begin{array}{c}\text { Type of } \\
\text { sandwich }\end{array}$ & $\begin{array}{c}\text { Ingredients } \\
{[\%]}\end{array}$ & $\begin{array}{c}\text { Preparation }^{\mathrm{a}} \\
{[\%]}\end{array}$ & $\begin{array}{c}\text { Retail }^{\mathrm{b}} \\
{[\%]}\end{array}$ & $\begin{array}{c}\text { Packaging } \\
{[\%]}\end{array}$ & $\begin{array}{c}\text { Waste } \\
\text { management } \\
{[\%]}\end{array}$ & $\begin{array}{c}\text { Transport } \\
{[\%]}\end{array}$ & $\begin{array}{c}\text { Carbon } \\
\text { footprint } \\
{\left[\mathbf{g ~ C O}_{2} \text {-eq.] }\right.}\end{array}$ \\
\hline Commercial & 65.1 & 13.9 & 13.3 & 4.5 & 0.8 & 2.4 & 1349.5 \\
Home-made & $88.6-91.9$ & 0.001 & $3.9-4.6$ & $1.8-3.5$ & $1.1-2.2$ & $0.7-1.8$ & $399-$ \\
\hline
\end{tabular}

\footnotetext{
${ }^{a}$ The preparation stage for the home-made sandwich includes only the refrigerated storage of cheese and ham.

${ }^{\mathrm{b}}$ The retail stage for the ready-made sandwich refers to the finalised product and for the home-made option it refers to the ingredients.
}

\subsection{Sensitivity analysis}

A number of scenarios were developed to test the sensitivity of the results to key influencing parameters for both the ready- and home-made sandwiches. The scenarios can be grouped according to the parameters varied one at a time, as follows:

- cultivation of ingredients (Scenarios 1-2);

- modifications of recipes (Scenarios 3-9);

- reduction of food waste (Scenario 10); and

- alternative packaging and waste management options (Scenarios 11-22).

These are detailed below.

\subsubsection{Cultivation of ingredients}

Scenarios 1 and 2 - Cultivation of tomato and lettuce: Given that the ingredients represent the hot spot in both sandwich systems, largely due to agricultural activities, changing the assumptions about the cultivation practices would influence the results. Scenarios 1 and 2 focus on the ready-made sandwiches and in particular on the cultivation practices for tomato and lettuce, which are used in five and three commercial recipes, respectively. Scenario 1 evaluates the cultivation practices for tomato and lettuce assuming lower carbon footprints, whereas Scenario 2 evaluates practices with the highest carbon footprints - for details, see Table 11. By comparison, tomato and lettuce were assumed in the base case to be cultivated indoors in the UK, using natural gas and electricity to heat the greenhouses for tomatoes and gas for lettuce (see Table 6). 
Accepted for publication in Sustainable Production and Consumption:

https://doi.org/10.1016/j.spc.2017.12.002

Table 11. Carbon footprint of tomato and lettuce according to different cultivation practices

\begin{tabular}{|c|c|c|c|c|}
\hline Product & Country & Agricultural practices & $\begin{array}{l}\text { Carbon footprint } \\
\text { [kg CO} 2 \text { eq./ } \\
\text { kg product] }\end{array}$ & Source \\
\hline Tomato & UK & $\begin{array}{l}\text { Conventional, oil-heated } \\
\text { greenhouse }\end{array}$ & $2.30^{\mathrm{a}}$ & DEFRA (2009a) \\
\hline Tomato & UK & $\begin{array}{l}\text { Conventional, waste heat- } \\
\text { heated greenhouse }\end{array}$ & $0.39^{b}$ & DEFRA (2009a) \\
\hline Tomato & UK & $\begin{array}{l}\text { Conventional, natural gas- } \\
\text { heated greenhouse; electrical } \\
\text { lighting }\end{array}$ & $5.90^{\mathrm{C}}$ & Williams et al. (2006) \\
\hline Tomato & Spain & Conventional & 1.80 & DEFRA (2009a) \\
\hline Tomato & Spain & $\begin{array}{l}\text { Conventional, unheated } \\
\text { greenhouse }\end{array}$ & 0.168 & Muñoz et al. (2010) \\
\hline Lettuce & UK & Conventional, outdoors & $0.33 \pm 0.08$ & Hospido et al. (2009) \\
\hline Lettuce & UK & $\begin{array}{l}\text { Conventional, gas-heated } \\
\text { greenhouses }\end{array}$ & $2.62 \pm 1.57^{\mathrm{a}, \mathrm{c}}$ & Hospido et al. (2009) \\
\hline Lettuce & UK & $\begin{array}{l}\text { Conventional, unheated } \\
\text { greenhouses }\end{array}$ & $0.24^{b}$ & Hospido et al. (2009) \\
\hline Lettuce & Spain & Conventional, outdoors & $0.45 \pm 0.09$ & Hospido et al. (2009) \\
\hline
\end{tabular}

\subsubsection{Recipe modifications}

Scenario 3 - Wholemeal bread: This scenario assumes the replacement of white bread with the same amount of wholemeal bread for all ready-and home-made sandwiches. Wholemeal bread has both a lower energy content (assumed at $247 \mathrm{kcal}$ per $100 \mathrm{~g}$ ) and the carbon footprint (Espinoza-Orias et al., 2011) than white bread.

Scenarios 4-6 - No tomato, lettuce and mayonnaise: Tomato and lettuce are ingredients with a relatively low energy content but can have significant carbon footprints, depending on the cultivation practices considered. Mayonnaise, on the other hand, has a high energy content but low carbon footprint. Scenarios 4-6 explore the consequences of excluding these three ingredients, one at a time, as an option to reduce carbon footprint of both ready-made and home-made sandwiches (where applicable). Excluding mayonnaise, which is a ubiquitous sandwich filling, would also reduce the energy (and fat) content, in the interest of a healthier diet.

Scenarios 7-9 - Reduced amount of ingredients: An alternative approach to reducing the carbon footprint of sandwiches (and the energy content) would be to reduce the amount of key ingredients such as meat, cheese and eggs. Scenarios 7 to 9 test the effect of the reduction in the amount of meat by $10 \%$, cheese by $20 \%$ and eggs by $10 \%$. These scenarios were evaluated for all applicable ready-to eat sandwiches.

\subsubsection{Reducing food waste}

Scenario 10 - Reduction in food waste along the supply chain: This scenario explores the effect on the carbon footprint of ready-made sandwiches of reducing food waste in the supply chain by $10 \%$.

\subsubsection{Packaging and waste management}

Scenarios 11-22 - Alternative packaging and waste management options: To examine the influence of packaging on the carbon footprint of ready-to-eat sandwiches, the base-case PET tray and film are assumed to be replaced in Scenarios 11-22 by the following alternatives:

- cardboard packaging, weighing $13.5 \mathrm{~g}$ (based on products available on the market); 
- light-weight plastic packaging (PET) weighing $7 \mathrm{~g}$ (based on products available on the market); and

- mixed materials packaging, consisting of a plastic film (PET) weighing $2 \mathrm{~g}$ and cardboard weighing $5 \mathrm{~g}$ (WRAP, 2010b).

In addition to different packaging materials, these scenarios also consider different alternative waste management options, summarised in Table 12. The GHG emission factors applicable to these options were taken from DEFRA (2007).

Table 12. Alternative waste management options

\begin{tabular}{clll}
\hline Scenario & Food waste & Cardboard waste & Plastic waste \\
\hline 11 & Anaerobic digestion & Composting & Recycling \\
12 & Anaerobic digestion & Composting & Energy recovery \\
13 & Anaerobic digestion & Energy recovery & Recycling \\
14 & Anaerobic digestion & Energy recovery & Energy recovery \\
15 & Energy recovery & Composting & Recycling \\
16 & Energy recovery & Composting & Energy recovery \\
17 & Energy recovery & Energy recovery & Recycling \\
18 & Energy recovery & Energy recovery & Energy recovery \\
19 & Composting & Composting & Recycling \\
20 & Composting & Composting & Energy recovery \\
21 & Composting & Energy recovery & Recycling \\
22 & Composting & Energy recovery & Energy recovery \\
\hline
\end{tabular}

3.4.5 Results of the sensitivity analysis

Table 13 summarises the results for all 22 scenarios for both ready- and home-made sandwiches. With the exception of Scenario 3, all other scenarios show reductions in the carbon footprint of commercial sandwiches from 0.1 to $11.1 \%$ and in the energy content from $0.6 \%$ $19.7 \%$. The impact from home-made sandwiches reduces by $0.6 \%-9.1 \%$ and the energy content by $2.9 \%-10.9 \%$. These results are discussed in more detail below.

Scenarios 1-2: The agricultural practices used to cultivate tomato and lettuce in the UK have significant effect on the overall carbon footprint of ready-made sandwiches. Cultivating tomatoes in greenhouses heated by waste heat and growing lettuce in warmer seasons to avoid heating the greenhouses (Scenarios 1), reduces the overall carbon footprint by $6.9 \%-11.1 \%$. In contrast, heating tomato greenhouses by electricity and lettuce by natural gas (Scenario 2 ) increases the impact by $5.1 \%-14 \%$.

Scenario 3: The change from white to wholemeal bread results in a similar reduction in the energy content of ready-to-eat and home-made sandwiches. The carbon footprint of both types of sandwich also reduces but in different proportions. A negligible reduction is observed for the commercial sandwiches $(<0.1 \%)$ while for the home-made the impact is lower by up to $2.1 \%$. This is due to the differences in the amount of bread used as well as the manufacture of bread (bread for general purposes used in home-made sandwiches as opposed to specialist sandwich bread used in commercial sandwiches).

Scenarios 4-6: The exclusion of tomato and lettuce from the sandwich recipes leads to small reductions in the energy content of sandwiches (0.8\%-1.5\%) but more significant improvements in the overall carbon footprint $(3.3 \%-8.9 \%)$. A similar reduction in the impact is achieved by excluding mayonnaise: $1.7 \%-8.4 \%$ for ready-made and $4.3 \%-9.1 \%$ for home-made sandwiches. However, the reduction in the energy content is higher: $3.9 \%-19.7 \%$ and $5.8-10.9 \%$, respectively. 
Table 13. Results of the sensitivity analysis for ready-made and home-made sandwiches

\begin{tabular}{|c|c|c|c|c|}
\hline \multirow{3}{*}{$\begin{array}{c}\text { Base case } \\
{\left[\mathrm{CO}_{2} \text {-eq./sandwich] }\right.} \\
{[\mathrm{kcal} / \text { sandwich }]^{-}} \\
\text {Scenarios }^{\mathrm{a}}\end{array}$} & \multicolumn{2}{|c|}{$\begin{array}{c}\text { Commercial sandwiches } \\
739.0-1441.3 \\
279-546\end{array}$} & \multicolumn{2}{|c|}{$\begin{array}{c}\text { Home-made sandwiches } \\
399.0-843.2 \\
274-518\end{array}$} \\
\hline & \multicolumn{4}{|c|}{ Variation in the results relative to the base case [\%] } \\
\hline & $\begin{array}{c}\text { Carbon } \\
\text { footprint }\end{array}$ & $\begin{array}{l}\text { Energy } \\
\text { content }\end{array}$ & $\begin{array}{c}\text { Carbon } \\
\text { footprint }\end{array}$ & $\begin{array}{l}\text { Energy } \\
\text { content }\end{array}$ \\
\hline 1 - Low CF for tomato \& lettuce & $(-11.1)-(-6.9)$ & N.A. & & \\
\hline 2 - High CF for tomato \& lettuce & $5.1-14.0$ & N.A. & & \\
\hline 3 - Wholemeal bread & $<-0.1$ & $(-5.4)-(-2.8)$ & $(-2.1)-(-0.6)$ & $(-5.1)-(-2.9)$ \\
\hline 4 - No tomato & $(-8.9)-(-3.3)$ & $(-1.5)-(-0.8)$ & & \\
\hline 5 - No lettuce & $(-5.4)-(-5.1)$ & $(-0.8)-(-0.6)$ & & \\
\hline 6 - No mayonnaise & $(-8.4)-(-1.7)$ & $(-19.7)-(-3.9)$ & $(-9.1)-(-4.3)$ & $(-10.9)-(-5.8)$ \\
\hline $7-10 \%$ less meat & $(-5.6)-(-2.5)$ & $(-4.3)-(-1.1)$ & & \\
\hline $8-20 \%$ less cheese & $(-10.0)-(-5.3)$ & $(-8.6)-(-5.8)$ & & \\
\hline $9-10 \%$ less egg & $(-3.9)-(-1.1)$ & $(-3.1)-(-1.2)$ & & \\
\hline $10-10 \%$ reduction of food waste & $(-8.5)-(-3.1)$ & N.A. & & \\
\hline 11 - Cardboard & $(-6.8)-(-3.7)$ & N.A. & & \\
\hline 12 - Cardboard & $(-6.8)-(-3.7)$ & N.A. & & \\
\hline 13 - Cardboard & $(-7.2)-(-3.9)$ & N.A. & & \\
\hline 14 - Cardboard & $(-7.2)-(-3.9)$ & N.A. & & \\
\hline 15 - Cardboard & $(-8.4)-(-4.5)$ & N.A. & & \\
\hline 16 - Cardboard & $(-8.4)-(-4.5)$ & N.A. & & \\
\hline 17 - Cardboard & $(-8.7)-(-4.7)$ & N.A. & & \\
\hline 18 - Cardboard & $(-8.7)-(-4.7)$ & N.A. & & \\
\hline 19 - Cardboard & $(-6.8)-(-3.7)$ & N.A. & & \\
\hline 20 - Cardboard & $(-6.8)-(-3.7)$ & N.A. & & \\
\hline 21 - Cardboard & $(-7.1)-(-3.9)$ & N.A. & & \\
\hline 22 - Cardboard & $(-7.1)-(-3.9)$ & N.A. & & \\
\hline 11 - Light-weight plastic & $(-5.6)-(-3.1)$ & N.A. & & \\
\hline 12 - Light-weight plastic & $(-4.4)-(-2.5)$ & N.A. & & \\
\hline 13 - Light-weight plastic & $(-5.6)-(-3.1)$ & N.A. & & \\
\hline 14 - Light-weight plastic & $(-4.4)-(-2.5)$ & N.A. & & \\
\hline 15 - Light-weight plastic & $(-7.2)-(-3.9)$ & N.A. & & \\
\hline 16 - Light-weight plastic & $(-5.9)-(-3.3)$ & N.A. & & \\
\hline 17 - Light-weight plastic & $(-7.2)-(-3.9)$ & N.A. & & \\
\hline 18 - Light-weight plastic & $(-5.9)-(-3.3)$ & N.A. & & \\
\hline 19 - Light-weight plastic & $(-5.6)-(-3.1)$ & N.A. & & \\
\hline 20 - Light-weight plastic & $(-4.3)-(-2.5)$ & N.A. & & \\
\hline 21 - Light-weight plastic & $(-5.6)-(-3.1)$ & N.A. & & \\
\hline 22 - Light-weight plastic & $(-4.3)-(-2.5)$ & N.A. & & \\
\hline 11 - Mixed packaging & $(-7.8)-(-4.2)$ & N.A. & & \\
\hline 12 - Mixed packaging & $(-7.5)-(-4.1)$ & N.A. & & \\
\hline 13 - Mixed packaging & $(-8.0)-(-4.3)$ & N.A. & & \\
\hline 14 - Mixed packaging & $(-7.6)-(-4.1)$ & N.A. & & \\
\hline 15 - Mixed packaging & $(-9.4)-(-5.0)$ & N.A. & & \\
\hline 16 - Mixed packaging & $(-9.4)-(-4.9)$ & N.A. & & \\
\hline 17 - Mixed packaging & $(-9.5)-(-5.1)$ & N.A. & & \\
\hline 18 - Mixed packaging & $(-9.1)-(-4.9)$ & N.A. & & \\
\hline 19 - Mixed packaging & $(-7.7)-(-4.2)$ & N.A. & & \\
\hline 20 - Mixed packaging & $(-7.4)-(-4.0)$ & N.A. & & \\
\hline 21 - Mixed packaging & $(-7.9)-(-4.3)$ & N.A. & & \\
\hline 22 - Mixed packaging & $(-7.5)-(-4.1)$ & N.A. & & \\
\hline
\end{tabular}


As mentioned earlier, mayonnaise is one of the most widely used ingredients in sandwiches and excluding it from the recipes would be difficult. The reasons for that are not only taste-related but also because it fulfils important functions as a filling ingredient. First, it acts as a barrier between the filling and the bread, preventing the migration of moisture and the bread from turning soggy. Secondly, being oily, it is easily spread over bread and can be used as a carrier for other filling ingredients (for example, pieces of chicken, tuna, sweetcorn, grated cheese). This is of particular relevance in automated sandwich assembly lines. Therefore, any changes in the recipe formulation involving mayonnaise ought to preserve its functionality and not affect the quality and taste of sandwiches.

Scenarios 7-9: Small reductions (10\%-20\%) in the quantity of meat, eggs and cheese reduce the carbon footprint from $1.1 \%$ to $10 \%$; a similar reduction in the energy content of sandwiches is also observed $(1.1 \%$ to $8.6 \%)$. However, for changes in the formulation of traditional recipes to become adopted by sandwich manufacturers, extensive consumer trials would be necessary to ensure consumer acceptance. Furthermore, there is also a potential for the 're-bound' effect, whereby the reduced mass and energy content of the sandwich could lead to the consumption of more sandwiches (or other food) to satiate consumer's appetite, hence increasing the carbon footprint.

Scenario 10: Reducing food waste along the supply chain by $10 \%$, reduces the carbon footprint of ready-made sandwiches by $3.1 \%-8.5 \%$. This reduction in waste could be achieved in different ways, including better management of supply and demand to reduce waste from oversupply and the amount of unsold products. As mentioned earlier, around $20 \%$ higher mass of ingredients is needed to produce a sandwich than is actually sold, largely due to oversupply (6.5\%) and unsold products (10\%). The greatest potential, however, lies in reducing post-consumer waste, as the quantities are much larger than the unsold product (33\%), but this is more difficult to achieve as it requires behavioural and other changes involving the consumer.

Scenarios 11-22: The various combinations of alternative packaging materials and waste management options examined in these scenarios show a consistent reduction in the overall carbon footprint of commercial sandwiches while maintaining the original recipes; these range from $2.5 \%-9.5 \%$ (Table 13).

\section{Conclusions}

This study estimated the carbon footprint associated with the production and consumption of sandwiches, prepared commercially and at home. In total, 40 most popular recipes were considered. The carbon footprint of a ready-made sandwich ranges from $739 \mathrm{~g} \mathrm{CO}_{2}$ eq. for egg \& cress to $1441 \mathrm{~g} \mathrm{CO}_{2}$ eq. for the breakfast option. The carbon footprint of the most popular home-made sandwich (ham \& cheese) varies from 399-843 $\mathrm{g} \mathrm{CO}_{2}$ eq. per serving. The average impact from the home-made option (609 $\mathrm{g} \mathrm{CO}_{2}$ eq.) is 2.2 times lower than the impact from the commercial equivalent with the same ingredients (ham, cheese and mayonnaise).

The results indicate that the largest contributor to the carbon footprint of sandwiches is the agricultural production and processing of ingredients, accounting for $37.3-67.1 \%$ of GHG emissions for the ready-made sandwiches and $88.6-91.9 \%$ for the home-made, respectively. Being a high risk food product, sandwiches need to be kept within a cold chain, from the preparation to the retail stages. Hence, these stages accrue $13.1-24.6 \%$ and $12.4-24.2 \%$ of GHG emissions in the commercial sandwich system, respectively. The packaging materials account for $4.3-8.5 \%$ of the emissions and transport of materials (including refrigerated transport of sandwiches) adds a further $2.2-4.3 \%$. The contribution of waste management is small (0.8-1.3\%). For home-made sandwiches, the retail of ingredients accounts for $3.9-4.6 \%$ of 
the total carbon footprint, packaging materials $1.8-3.5 \%$ and waste management $1.1-2.2 \%$; the remaining $0.7-1.8 \%$ is from transport.

Variations in the cultivation practices for tomato and lettuce affect significantly the carbon footprint of sandwiches, which ranges from $-11.1 \%$ to $14.0 \%$ relative to the base case. Changes in the recipes can also influence significantly the carbon footprint. For example, small reductions in the amount of meat, eggs and cheese used in ready-made sandwiches reduce the impact by $1.1-10 \%$. Excluding tomato and lettuce lowers the carbon footprint by $3.3 \%-8.9 \%$ and not using mayonnaise yields a further reduction of $1.7 \%-8.4 \%$. Similar reductions can be achieved by reducing the amount of food waste in the supply chain $(3.1 \%-8.5 \%)$ and by adopting waste management options other than landfilling, combined with changes in sandwich packaging (2.5\%-9.5\%). Substituting white bread with wholemeal bread achieves a very limited reduction in the carbon footprint $(<0.1 \%)$. Thus, combining these improvement opportunities could reduce the carbon footprint of commercial sandwiches by up to $50 \%$. However, any changes to the sandwich recipes, aimed at reducing the carbon footprint, need to be acceptable to consumers and, in turn, to sandwich producers. In addition to taste, other requirements must be considered, including product quality, safety, ease of preparation in commercial conditions and nutritional value. This work indicates that there is no clear relationship between the latter and the carbon footprint of sandwiches. Nevertheless, the other improvement opportunities which do not involve recipe changes could reduce the carbon footprint of commercial sandwiches by up to $20 \%$.

Another emerging option (beyond the scope of this work) includes changing the labelling of food to increase the use-by date as this is usually quite conservative. Commercial sandwiches undergo rigorous shelf-life testing and are normally safe for consumption beyond the use-by date stated on the label. BSA estimate that extending their shelf life by relaxing the this date would help save at least 2000 tonnes of sandwich waste annually. A recent initiative in the UK is aimed at this, allowing retailers to re-label short-shelf life chilled foods which can then be donated to charities to redistribute surplus foods to those who need them.

The findings from this work also suggest that home-made sandwiches have significantly lower carbon footprint than the ready-made for an equivalent recipe. Although the study here was limited to one, most popular, type of home-made sandwich (ham \& cheese), the relative differences between home-made and commercial sandwiches for other recipes are expected to be similar for the same ingredients. This is because of the relatively high contributions of sandwich preparation and the cold chain to the carbon footprint of commercial sandwiches, which are avoided in the home-made equivalents. A further potential benefit of home-made sandwiches is that they can be made from leftovers, helping to reduce the amount of food waste, which is not possible for commercially-produced sandwiches.

Nevertheless, while comparisons of the carbon footprints of the two types of sandwich system can be made relatively easily, it is difficult to compare them on other aspects. While consumers may prefer home-made sandwiches for their taste and lower cost, which may be the reason why half of all sandwiches in the UK are made at home, they also appreciate convenience and are prepared to pay for that. Thus, arguably the questions is not of choosing one over another, but rather of how both systems can be improved to reduce their carbon footprints. It is hoped that this work provides some answers to this question.

\section{Acknowledgements}

This work was funded by the UK Research Councils within the CSEF project (Grant no. $\mathrm{EP} / \mathrm{K} 011820 / 1$.). This funding is acknowledged gratefully. 


\section{References}

Anonymous (1989). Sandwich, n. ${ }^{2}$ The Oxford English Dictionary, 2nd ed. OED Online. Oxford University Press. 1989.

Bartlett, C. (2010). Mapping waste in the food \& drink industry. Oakdene Hollins Research \& Consultancy. Report for DEFRA and the Food and Drink Federation, November 2010.

BSA (2007). Code of practice and minimum standards for sandwich manufacturers (producers). British Sandwich Association, 2007.

BSA (2008). Britain's favourite sandwich fillers by market share and how their popularity is changing. British Sandwich Association, Chepstow, UK.

BSA (2010). Britain's favourite sandwiches. British Sandwich Association, Chepstow, UK.

BSA (2017). How many sandwiches to we eat? British Sandwich Association, Chepstow, UK. www.britishsandwichweek.com/index.php/facts-figures/3-how-many-sandwiches-do-we-eat.

BSI (2005). BSI EN ISO 23953-2:2005 Refrigerated display cabinets, Part 2: Classification, requirements and test conditions. British Standards Institute, London, 2005.

BSI (2011). PAS 2050:2011. Specification for the assessment of the life cycle greenhouse gas emissions of goods and services. British Standards Institute, London, 2011.

Coca Cola (2017). Carbon Label of Coca Cola, 500 cc PET bottle. Coca Cola, 2017. http://www.coca-cola.co.uk/environment/what-s-the-carbon-footprint-of-a-coca-cola.html

DEFRA (2007). Waste Strategy for England. Department for Environment, Food and Rural Affairs, London, 2007.

DEFRA (2009a). Scenario building to test and inform the development of a BSI method for assessing greenhouse gas emissions from food. Report to Defra, Project Reference Number: FO0404. ADAS, London, 2009.

DEFRA (2009b). Greenhouse gas impacts of food retailing. Project FO405. Department for Environment, Food and Rural Affairs, London, London, 2009.

DEFRA/DECC (2010). Department for Environment, Food and Rural Affairs (DEFRA) and Department for Energy and Climate Change (DECC). 2010 Guidelines to DEFRA/DECC's GHG conversion factors for company reporting. V.1.2.1 Final, October 2010.

Ecoinvent (2010). Ecoinvent Database v 2.2. Swiss Centre for Life Cycle Inventories, Dübendorf, 2010.

Espinoza-Orias, N., H. Stichnothe and A. Azapagic (2011). The carbon footprint of bread. International Journal of Life Cycle Assessment, 16 (4) 351-365.

Goodburn, K. (2010). Foodborne Disease Strategy: Focus on Listeria. Chilled Food Association, 2010.

ISO (2006a). ISO 14040:2006: Environmental management - Life cycle assessment - Principles and framework. Geneva, Switzerland, International Organisation for Standardisation.

ISO (2006b). ISO 14044:2006: Environmental management - Life cycle assessment Requirements and guidelines. Geneva, Switzerland, International Organisation for Standardisation.

JRC (2006). Integrated Pollution Prevention and Control. Reference Document on Best Available Techniques in the Food, Drink and Milk Industries. JRC, Seville, 2006.

Hospido, A., M.E. Vazquez, A. Cuevas, G. Feijoo and M.T. Moreira (2006). Environmental Assessment of Canned Tuna Manufacture with a Life Cycle Perspective. Resources, Conservation \& Recycling, 47, 56-72.

Hospido, A., L. Milà i Canals, S. McLaren, M. Truninger, G. Edwards-Jones (2009). The Role of Seasonality in Lettuce Consumption: A Case Study of Environmental and Social Aspects. International Journal of Life Cycle Assessment, 14(5) 381-391.

HMSO (2006). Food Hygiene (England) Regulations 2006. Her Majesty's Stationery Office, 2006.

Innocent (2009). Carbon Label of Innocent Banana and Strawberry Smoothie, 250 cC PET bottle. Innocent, 2009. 
IFIS (2009). Dictionary of Food Science and Technology, $2^{\text {nd }}$ ed., International Food Information Service. IFIS Publishing, 2009.

Kikkoman (2009). Kikkoman Group Corporate Citizenship Report 2009. www.kikkoman.com.

Muñoz, I., P. Campra, A. Fernández-Alba (2010). Including $\mathrm{CO}_{2}$-emission Equivalence of Changes in Land Surface Albedo in Life Cycle Assessment. Methodology and Case Study on Greenhouse Agriculture. International Journal of Life Cycle Assessment, 15(7) 672-681.

Nielsen, P.H., A.M. Nielsen, B.P. Weidema, R. Dalgaard and N. Halberg (2003). LCA Food Database. www.lcafood.dk.

Unilever (2010). Unilever Sustainable Development Overview 2009: Creating a Better Future Every Day. www.unilever.com.

Walkers (2009). Carbon Label of Walkers Potato Crisps. Walkers, 2009.

Williams, A.G., E. Audsley and D.L. Sandars (2006). Determining the environmental burdens and resource use in the production of agricultural and horticultural commodities. Main report. DEFRA Research project IS0205, Bedford, Cranfield University and DEFRA, 2006.

WRAP (2010a). Waste Arisings in the Supply of Food and Drink to Households in the UK. Waste \& Resources Action Programme, Banbury, Oxon, 2010.

WRAP (2010b). Case studies. Courtauld Commitment 1 (2005-2010). Examples of household packaging optimisation and food waste. Waste \& Resources Action Programme, Banbury, Oxon, 2010. 